\title{
THE INTEGRATED APPROACH TO THE FORMATION OF THE BANKING BUSINESS FINANCIAL AND ECONOMIC SECURITY SYSTEM
}

\begin{abstract}
Анотація. У статті досліджено сутність фінансово-економічної безпеки банківських установ у широкому і вузькому сенсі. Виділено три основні компоненти системи забезпечення безпеки сучасних банківських установ: інформаційна безпека банку, безпека персоналу банку і майнова безпека банку. Виділено основні загрози зовнішнього та внутрішнього характеру, які слід врахувати при формуванні системи забезпечення безпеки банківського бізнесу. Під час формування інтегрованої системи забезпечення фінансово-економічної безпеки банківського бізнесу запропоновано здійснити аналіз та оцінювання відповідності банківського сектору тому або іншому рівню безпеки.
\end{abstract}

Ключові слова: фінансово-економічна безпека, зовнішні та внутрішні загрози банку, інформаційна і майнова безпека банку, безпека персоналу банку.

Summary. The article investigates the essence of financial and economic security of banking institutions in a broad and narrow sense. There are three main components of the security system of modern banking institutions: information security of the bank, security of bank staff and property security of the bank. The main threats of external and internal character, which should be taken into account when forming the system of security of banking business, are highlighted. In forming an integrated system for ensuring the financial and economic security of the banking business, it is proposed to analyze and evaluate the compliance of the banking sector to a given level of security.

Key words: financial and economic security, external and internal threats of the bank, information and property security of the bank, security of bank staff.

$$
\text { DOI : 10.33783/1977-4167-2020-47-1-127-130 }
$$

Formulation of the problem. Banking security is not only the foundation of safe functioning and the ability to further develop the banking business, but also the creation of a conflict-free external environment that is an important factor in the modern development of the banking services market. It is commercial banks that can, on the one hand, fully secure the country's economy from the financial crisis or at least reduce its impact; On the other hand, it is commercial banks that are the main indicators of the country's financial and economic vulnerability.

In a competitive economic environment, banking has become an area of high risk, which makes legal regulation of the financial and economic security of banking a very difficult process.

In recent years, several practical measures have been implemented in Ukraine aimed at improving the level of financial and economic security of the banking business. The Government of Ukraine and the NBU have formed a sufficient system of regulatory, organizational and legal security for banking security. The banks themselves also do not stay on the sidelines - they are constantly taking steps to increase the level of security of the system of financial and economic security.
However, the financial and economic security of the banking business in Ukraine largely fails to meet the needs, and the state of protection against criminal offenses leaves much to be desired. In order to protect the banks from criminal offenses, it is necessary to scientifically process the problem and get a complete picture of an integrated approach to the formation of the system of financial and economic security of the banking business.

Analysis of recent research and publications. The following foreign scientists were engaged in the study of problems of economic security: R. Bernd, G. Johnson, E. Dolan, F. Mishkin, L. Harris, Z. Bohr, E. Zhukov, L. Krasavin, V. Kolesnikov, O. Lavrushin, V. Milovidov, G. Panova, A. Pattox, S. Piatenko, V. Usoskin, L. Hoffman, P. Schweizer, and others. The questions of ensuring the financial and economic security of banking institutions are devoted to the works of domestic scientists, such as: V. Arefiev, E. Balatsky, A. Baranovsky, I. Belomistn, O. Vasylik, V. Vitlinsky, O. Vovchak, A. Galchinsky, A. Danilenko, M. Zubka, T. Kuzenko, N. Kostina, I. Lyuty, A. Nikiforov, O. Orlyuk, O. Pylypchenko, O. Sharov, and many others.

(C) Самура Ю. О., Вареник В. А., 2020

Бібліографія ДСТУ 8302:2015:

Samura Yu. O., Varenyk V. A. The integrated approach to the formation of the banking business financial and economic security system. Вісник Бердянського університету менеджменту і бізнесу. 2020. № 1 (47). С. 127-130.

References (APA):

Samura, Yu. O., Varenyk, V. A. (2020). The integrated approach to the formation of the banking business financial and economic security system. Visnyk Berdianskoho universytetu menedzhmentu i biznesu, 1 (47), 127-130 (in Ukr.). 
However, at present, there is no integrated approach to the formation of the system of financial and economic security of banking business in the domestic and foreign economic literature.

The aim of the study. The purpose of this article is to theoretically and practically summarize the existing approaches, as well as to highlight the generalized approach to the formation of the system of financial and economic security of the banking business.

Presenting of the main research material. The Law of Ukraine «On National Security of Ukraine» of June 22, 2018 No. 2469-VIII defines security as a state of protection of vital interests of the individual, society and state from internal and external threats. Security threat is defined by the above law as a set of minds and factors that create the danger of vital interests [1].

According to the above interpretation of security under the security of banking institutions in the broad sense, it is necessary to understand the state of protection of vital interests of banking business from internal and external threats (sources of security).
In a narrow sense, the security of the bank is this state of its legal, economic and productive relations, material, intellectual and informational resources, which express the capacity of banking institutions to ensure unprecedented functioning of credit and scientific and technical credit.

The study of theoretical and methodological foundations of banking security allows us to formulate three main components of the system of financial and economic security of modern banking institutions:

- information security of the bank, security separating it from any threats of disclosure or loss of information of commercial or other value;

- security of the Bank's personnel, protection that eliminates it from any threats to the personnel, first of all, highly qualified employees;

- property security of the bank, protection that removes it from any threats of loss of cash, securities, inventory and other assets [2, p. 57].

There are a number of threats to the financial and economic security of internal and external banking institutions, presented in Table. 1.

Table 1

The main threats in the forming of an integrated system of financial and economic security of the banking business (complied on the basis of $[4$, p. 223])

\begin{tabular}{|l|l|}
\hline \multicolumn{1}{|c|}{ Threats of an external nature } & \multicolumn{1}{|c|}{ Threats of an internal nature } \\
\hline $\begin{array}{l}\text { Adverse macroeconomic conditions: general } \\
\text { economic situation in the country and the region }\end{array}$ & $\begin{array}{l}\text { Unqualified management, errors in strategic planning and forecasting of } \\
\text { the bank, analysis of equity and profit, identification of sources of capital } \\
\text { growth in making tactical decisions }\end{array}$ \\
\hline $\begin{array}{l}\text { The degree of stability of the regulatory frame- } \\
\text { work and government crises }\end{array}$ & $\begin{array}{l}\text { Insufficient liquidity of the bank's assets and as a result of non-compli- } \\
\text { ance with the economic standards of the NBU }\end{array}$ \\
\hline Inflation rate and inflation expectations & $\begin{array}{l}\text { Lack of sufficient qualification of the bank's employees, insufficient hu- } \\
\text { man resources to solve primary tasks in the formation of an integrated } \\
\text { system of financial and economic security of banking }\end{array}$ \\
\hline Variability of fiscal, monetary and credit policy & $\begin{array}{l}\text { Non-repayment of loans to the bank by insolvent borrowers and non- } \\
\text { receipt of income due to high-risk lending activities }\end{array}$ \\
\hline $\begin{array}{l}\text { Insufficiency of investment resources, fluctua- } \\
\text { tions in foreign exchange rates }\end{array}$ & $\begin{array}{l}\text { Weak marketing coverage of the banking services market as a result, in- } \\
\text { sufficient diversification of services provided by the bank, lack of banking } \\
\text { advertising }\end{array}$ \\
\hline $\begin{array}{l}\text { Unfavorable criminogenic situation, spread of } \\
\text { criminal and financial crimes in the banking } \\
\text { business }\end{array}$ & $\begin{array}{l}\text { Existence of channels of leakage of banking secrecy and errors in the } \\
\text { organization of the system of preservation of financial and material val- } \\
\text { ues of the bank }\end{array}$ \\
\hline
\end{tabular}

As can be seen from the table. 1, the list of external threats that should be considered in the formation of an integrated system for ensuring the financial and economic security of banking business is quite large. The specified threats to banking institutions should be overcome under conditions that have a destabilizing effect on the banking sector as a whole. External threats to financial and economic security are understood to be regulators that are formed outside the bank and affect its activity from the outside, warnings in the implementation of risky credit policy, weak control over borrowers and financial institutions.

The main tools that prevent the impact on the financial and economic security of the bank from the outside are: licensing of commercial banks, organi- zation of banking audit, organization of banking supervision, identification of troubled banks and work to prevent their bankruptcy. Most of these regulators are the prerogative of the National Bank of Ukraine. Internal financial regulators are formed in the bank itself, since the main condition for profitable and reliable work is quality management, level of financial management, organization of internal control and audit, which largely depends on honesty and competence [5, p. 307].

When forming an integrated system for ensuring the financial and economic security of banking institutions, it is necessary to analyze and evaluate the compliance of the banking sector to one or another level of financial and economic security (Table 2). 
Indications in the forming of an integrated system of financial and economic security of banking institutions (complied on the basis of [6, p. 67])

\begin{tabular}{|l|l|}
\hline \multicolumn{1}{|c|}{$\begin{array}{c}\text { The level of financial and economic } \\
\text { security of the banking business }\end{array}$} & $\begin{array}{l}\text { Indicators that characterize the compliance of the banking sector to a particular } \\
\text { level of financial and economic security }\end{array}$ \\
\hline $\begin{array}{l}\text { 1. Compliance with the legal require- } \\
\text { ments of the legislation of Ukraine: } \\
\text { measures to combat money laundering }\end{array}$ & Cash transfer ratio (ratio of cash turnover to balance sheet currency \\
\cline { 2 - 2 } & $\begin{array}{l}\text { Observance of admissible values o indicators calculated in accordance with the } \\
\text { Regulations on the procedure for analysis and verification documents (informa- } \\
\text { tion) on foreign exchange transactions by authorized institutions }\end{array}$ \\
\hline $\begin{array}{l}\text { 2. Observance of normative legal acts of } \\
\text { the National Bank of Ukraine }\end{array}$ & $\begin{array}{l}\text { Satisfaction of financial stability indicators that meet the requirements of the } \\
\text { Regulation on the assessment of the stability of banks and the banking system of } \\
\text { Ukraine dated 22.12.2017 № 141 }\end{array}$ \\
\hline $\begin{array}{l}\text { 3. Implementation of a simple type of } \\
\text { reproduction of the banking sector of } \\
\text { Ukraine }\end{array}$ & $\begin{array}{l}\text { Annual growth rates of key indicators (volume of income-generated assets, size of } \\
\text { resource base, capital adequacy) are lower or arrording the inflation rate }\end{array}$ \\
\hline $\begin{array}{l}\text { 4. Implementation of the investment } \\
\text { type of reproduction of the banking } \\
\text { sector }\end{array}$ & $\begin{array}{l}\text { Annual growth rates of key indicators (volume of income-generated assets, size of } \\
\text { resource base, capital adequacy) above the inflation rate }\end{array}$ \\
\hline $\begin{array}{l}\text { 5. Increasing the level of financial and } \\
\text { economic security of the banking busi- } \\
\text { ness }\end{array}$ & Coefficients of coverage f the population of Ukraine by banking services \\
\cline { 2 - 2 } & The share of assets of the banking sector in the formation of the country's GDP \\
\cline { 2 - 2 } & $\begin{array}{l}\text { Coefficients of transformation of the resource base into bank loans (the value } \\
\text { should be equal to one) }\end{array}$ \\
\hline
\end{tabular}

An integrated approach to analyzing and evaluating the financial and economic security of the banking business is a system of indicators on the basis of which it is advisable to evaluate the dynamics of the development of the banking sector

Some common methodological requirements must be followed in the formation, operation and development of an integrated system for ensuring the financial and economic security of banking institutions. The main of them is a systematic approach to the problem of financial and economic security. This refers to the inadmissibility of emphasizing the efforts of the Bank's security service to reflect any one or more potential threats to the detriment of others.

The second requirement in the formation of an integrated system for ensuring the financial and economic security of banking institutions is to determine the priority of measures to prevent potential threats (ie methods of preventive nature). It does not require additional justification by virtue of the possibility provided to prevent a bank loss in principle, while other methods at best allow it to reduce or punish the culprits.

The third requirement in the formation of an integrated system for ensuring the financial and economic security of banking institutions is the system's focus on ensuring priority protection of confidential information and only then other objects of potential threats. The role of information and information technology in the functioning of the modern banking system, the state, individual enterprises and households is steadily increasing. For a larger number of business entities, the loss or disclosure of information becomes a significant loss than the theft of cash and inventory. The emergence and development of global computer networks has led to the emergence of another source of constant threats to information security - unauthorized access to databases of banking institutions.

The fourth requirement in the formation of an integrated system is the direct participation in ensuring the financial and economic security of all its structural units and employees within the limits of their established competence and responsibility. The structure of possible threats, among which the last place is occupied by threats from own personnel, prevent the effective counteracting of them only by the employees of the Bank's security service.

The fifth requirement in the formation of an integrated system for ensuring the financial and economic security of banking institutions is to ensure the interaction of the security management system with other areas of management. This requirement is implemented both at the strategic and operational level of the management system. The next section of the integrated approach examines specifically the dependence of the financial and economic security strategy on the overall mission of the bank and its competitive strategy. In the domestic minds, in the mode of operational management, the closest connection must be ensured between the system and personal management. Violation of the requirement to coordinate the management of different activities can lead to extremely negative consequences. When the development of related management systems (such as financial management or marketing) violates the requirements of this system, the likelihood of negative implementation of those that meet the threats will increase. In turn, the normal functioning of adjacent management systems will be constantly disrupted if security management is organized on the principle of self-sufficiency - security for the sake of security itself. Thus, a complex management system should be formed 
taking into account the provision of relative parity or balance of interests of each of the areas of activity of.

The sixth requirement in the formation of an integrated system is the proportionality of the costs of ensuring the financial and economic security of banking institutions to the real level of threats. It is connected with the realization of the principle of reasonable sufficiency. From the point of view of the ultimate efficiency of the system, it is equally unacceptable to economize on this area of activity, weakening our own security, and to exaggerate the possible threats by making unnecessary, that is, unpaid costs. Considering that the security service leadership is, for obvious reasons, prone to an increase in the level of potential threats, it is desirable to involve independent experts in the person of employees of state law enforcement agencies or private security structures in order to meet this requirement.

The final requirement for the formation of an integrated system for ensuring the financial and economic security of banking institutions is to formalize not only the functional responsibilities but also the powers (competences) of the security service. Unlike other activities of the bank, the work of the majority of employees of this unit is always associated with the threat of exceeding the authority. Analyzing and evaluating the effectiveness of financial and economic security management is a necessary element in the formation of an integrated bank security system. It allows to solve several applied problems, in particular, to perform statistical analysis of the likelihood of negative realization of certain external and internal threats, as well as to objectively evaluate the effectiveness of the activity of the security service.

Conclusions from this study. Thus, the knowledge and timely detection of threats to the security of business activity, careful elaboration of the schemes of displaying threats and elimination of their possible adverse consequences is an important element in the formation of an integrated system of financial and financial security, in its turn, it is capable of making a significant impact on the economic results and the moral and psychological state of the team. Thus, this integrated approach in the formation of the system of financial and economic security of the bank allows the head of a commercial bank to determine the basics of organizing the security of a credit institution, taking into account the local conditions of operation, as well as their possibilities of providing resources.

\section{Література}

1. Law of Ukraine (2018). About National safety of Ukraine. Retrieved from https://zakon.rada.gov. ua/laws/ show/z2469-19 (in Ukr.).
2. Vovchak, O., Samura, Yu., Sydorenro, V., Varenyk, V. (2013) Bankivska bezpeka [Bank safety]. Kyiv, Znannia Publ. (in Ukr.).

3. Kartuzov, Ye. (2012). Vyznachennya fnansovoi bezpeky pidpryyemstva ponyattya, zmist, znachennya $i$ funkcionalni aspekty [Definition of financial security of an enterprise: concept, content, meaning and functional aspects]. Aktualni problem ekonomiku, 8, 172-181 (in Ukr.).

4. Orlyk, O. (2015). Mekhanizm upravlinnya finansovo-ekonomichnoyu bezpekoyu pidpryyemstva ta yogo osnovni skladovi [Mechanism of management of financial and economic security of the enterprise and its main components]. Finansovo-kredytna diyalnist: problemy teorii i praktyky, 19 (2), 222-232 (in Ukr.).

5. Savchuk, A. (2014). Upravlinnja finansovoyu bezpekoyu komertsijnogo banku. [Management of commercial bank financial safety]. Finansovyj ta upravlinskyj oblik, 3, 306-307 (in Ukr.).

6. Sak, T. (2015). Finansovo-ekonomichna bezpeka komertsijnyh bankiv Ukrainy. [Financial-economic safety of commercial banks of Ukraine]. Ekonomichnyj chasopys SENU im. L. Ukrainky, 2, 66-71 (in Ukr.).

\section{References}

1. Law of Ukraine (2018). About National safety of Ukraine. Retrieved from https://zakon.rada.gov. ua/laws/ show/z2469-19 (in Ukr.).

2. Vovchak, O., Samura, Yu., Sydorenro, V., Varenyk, V. (2013) Bankivska bezpeka [Bank safety]. Kyiv, Znannia Publ. (in Ukr.).

3. Kartuzov, Ye. (2012). Vyznachennya fnansovoi bezpeky pidpryyemstva ponyattya, zmist, znachennya i funkcionalni aspekty [Definition of financial security of an enterprise: concept, content, meaning and functional aspects]. Aktualni problem ekonomiku, 8, 172-181 (in Ukr.).

4. Orlyk, O. (2015). Mekhanizm upravlinnya finansovo-ekonomichnoyu bezpekoyu pidpryyemstva ta yogo osnovni skladovi [Mechanism of management of financial and economic security of the enterprise and its main components]. Finansovo-kredytna diyalnist: problemy teorii i praktyky, 19 (2), 222-232 (in Ukr.).

5. Savchuk, A. (2014). Upravlinnja finansovoyu bezpekoyu komertsijnogo banku. [Management of commercial bank financial safety]. Finansovyj ta upravlinskyj oblik, 3, 306-307 (in Ukr.).

6. Sak, T. (2015). Finansovo-ekonomichna bezpeka komertsijnyh bankiv Ukrainy. [Financial-economic safety of commercial banks of Ukraine]. Ekonomichnyj chasopys SENU im. L. Ukrainky, 2, 66-71 (in Ukr.). 